Szegedi Tudományegyetem ÁOK Repülö- és Ürorvosi Tanszék

\title{
In memoriam Dr. Merényi Scholtz Gusztáv orvos altábornagy
}

\author{
Dr. Remes Péter ny. orvos ezredes, c. egyetemi docens \\ Kulcsszavak: Magyar Királyi Légierő Egészségügyi Szolgálata, Magyar Királyi \\ Repülöorvosi Intézet, Repülés és orvostudomány, dekompressziós ártalom, \\ a hypoxia megelözése, barokamra
}

\begin{abstract}
Dr. Merényi Scholtz Gusztáv (1895-1950) a magyar katonai repülőorvostan életre hívásában és megszervezésében szerzett elévülhetetlen érdemeket. A Trianon utáni Magyarországon eredményes szervezőmunkával a semmiből korszerü repülöegészségügyi szolgálatot teremtett.
\end{abstract}

Dr. Merényi Scholtz Gusztáv 1895. szeptember 8-án született Kassán. Felvidéki nemesi katonacsaládból származott, édesapja merényi Scholtz Gusztáv altábornagy (1868-1930) Lőcsén született, aki Mayer Irmától (Dr. Merényi Scholtz Gusztáv édesanyjától), elválva Daur Olgát vette feleségül. Második házasságból születtek Dr. Merényi Scholtz Gusztáv féltestvérei, Scholtz György tüzér tiszt és Scholtz Mária, aki Szentmártoni Darnay Hubert huszár ezredeshez ment feleségül. Ilyenképpen a közvetlen családtagok között négy magas rangú hivatásos katona is volt. A szintén löcsei születésü nagyapja, Merényi Scholtz Carl-Gusztáv (1836-1919) magyar királyi müszaki fötanácsos (a bánya és vaskohó tulajdonos Scholtz András és Páter AnnaLudovika fia) Ferenc József császártól kapott nemességet a merényi előnév használatával. Merény felvidéki község a Kassai kerület Gölnicbányai járásában. 1290-ben a Máriássy család szász bányászokkal te- lepítette be ezt a bányavidéket. A falu a 18. században indult fejlődésnek, amikor a területén több vashámor, később vasolvasztó üzemelt. A merényi nemesi előnevet kisbetűsen használták, először Dr. Merényi Scholtz Gusztáv használta időnként nagybetűsen családnévként (1. ábra).

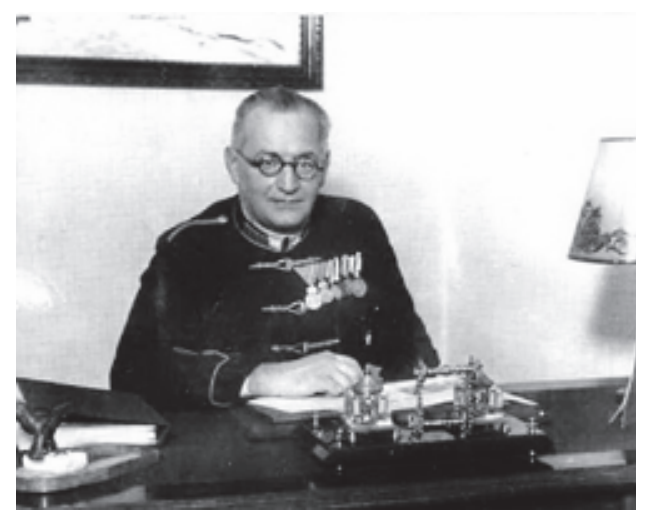

1. ábra. Dr. Merényi Scholtz Gusztáv orvos alezredes, a m. kir. légierők egészségügyi szolgálatának fönöke 1943-ban

DOI: $10.29068 / H O .2016 .3-4.72-83$ 
Származása tragikus módon járult hozzá ahhoz, hogy 1950-ben a nép ellenségének kiáltsák ki és mint „reakciós fasiszta" tisztet a demokratikus államrend megdöntésére irányuló szervezkedés miatt halálra ítéljék. Nem nevezhető szakszerünek, hogy a tábornokok perében $D r$. Merényi-nek titulálták, hiszen a fentiekben részletezett származása és névhasználata alapján nyilvánvaló, hogy Scholtz családról és nem Merényi családról van szó. Kezdetben leginkább a Dr. med. Scholtz Gusztáv nevet használta, közleményeit is így jegyezte [1]. 1942-ben jelent meg egy könyv a repülésről, amelyben „A repülés hatása az emberi szervezetre" címü fejezetet ő írta. Szerzőként már Dr. Merényi Scholtz Gusztáv van feltüntetve [2].

Félreérthetetlenül utal nemesi elönevére a Luftfahrtmedizin egyik 1943as számában megjelent német nyelvü közleménye is [3], ahol szerzőként „G. Scholtz v. Merényi"-ként van feltüntetve. Vagyis Scholtz von Merényi, mint nemesi előnév. 1943-ban például a Magyar Szárnyak „Scholtz orvosalezredes a m. kir. légierők egészségügyi szolgálatáról" címmel készített vele interjút [4]. A Magyar Szárnyak egy másik számában „Dr. Merényi-Scholtz Gusztáv egyetemi magántanár, orvosalezredes, a légierők orvosfőnöke"-ként is említik [5].

Nem szerencsés tehát, ha a koncepciós periratok óta Dr. Merényinek hívjuk és nem Dr. Merényi Scholtznak. Nem szerencsés még akkor sem, ha neve a síremlékén, emléktábláin, szobrán és a róla elnevezett kórház megnevezésében is helytelenül van feltüntetve.

Pozsonyban érettségizett, majd a Budapesti Tudományegyetem orvosi fakultásán tanult. 6 hónapos gyakorlati idejét a Szent János Kórházban, és egy berlini poliklinikán töltötte. 1920-ban avatták doktorrá.
Több tanulmányutat tett Németországban és Angliában. Hosszabb időt töltött Franciaországban, itt ismerkedett meg mélyebben a repülőorvostannal. Hazatérte után magánrendelőjében, az országban az elsők között kezdte meg a repülő-alkalmassági orvosi vizsgálatokat. Érdeklődése egyre inkább a repülés felé irányította, katonaorvosként a katonai repülés orvosi kérdéseivel foglalkozott.

A magyar repülö-egészségügyi szolgálat életre hívásában és megszervezésében elévülhetetlen érdemei voltak. A Légügyi Hivatalban hivatásos katonaorvosként, a Trianon utáni Magyarországon nehéz körülmények között a semmiből korszerü repülő-egészségügyi szolgálatot teremtett. Szervezőkészsége, vezetői adottságai kiemelték a repülőorvosok közül, orvos alezredesként hamarosan a légierő vezető orvosa lett. Ezt a beosztást nyolc éven keresztül (1936-1944) eredményesen látta el, a kor színvonalán álló magyar repülőegészségügyet hozott létre. Vezetésével kiváló repülőorvosi kar jött létre, amely szakmai munkájával és magas színvonalú tudományos kutatómunkájával nemzetközi elismerést vívott ki magának. A korábbi kezdetleges, sok szubjektív elemet tartalmazó repülőorvosi vizsgálati előírások helyett korszerű minősítő rendszert szervezett. Az általa bevezetett repülőorvosi alkalmassági eljárások tették lehetővé később a m. kir. Légierő pilótái számára, hogy a modern katonai repülési körülmények között is megállják a helyüket. Dr. Merényi Scholtz Gusztáv tevékenysége hozzájárult ahhoz, hogy a második világháborúban magassági repülésre vagy éppen zuhanóbombázásra is alkalmas, hadra fogható pilótákat lehessen bevetni, akár éjszaka bonyolult időjárási viszonyok között is. 
Az 1920-as években a Központi Orvosi Vizsgáló Intézet (K.O.V.I.) még a Légügyi Hivatalban müködött [6]. Fő feladata a hajózószemélyzet egészségi alkalmasságának elbírálása volt. A K.O.V.I. korszerü vizsgálóeszközökkel rendelkezett. Ennek az intézetnek a vezetőjeként vált Dr. Merényi Scholtz Gusztáv a repülöorvostan nemzetközileg is elismert szakemberévé. Törzséhez tartozott Dr. Gordon Helmut, Gyurik József, Szücs Gusztáv pszichológus, Dr. Rados Imre fogorvos és Firiczky Pál anyagellátó is. Munkatársai és tanítványai közül Dr. Gordon Helmut és Dr. Halm Tibor szereztek maguknak később hírnevet (2. ábra).

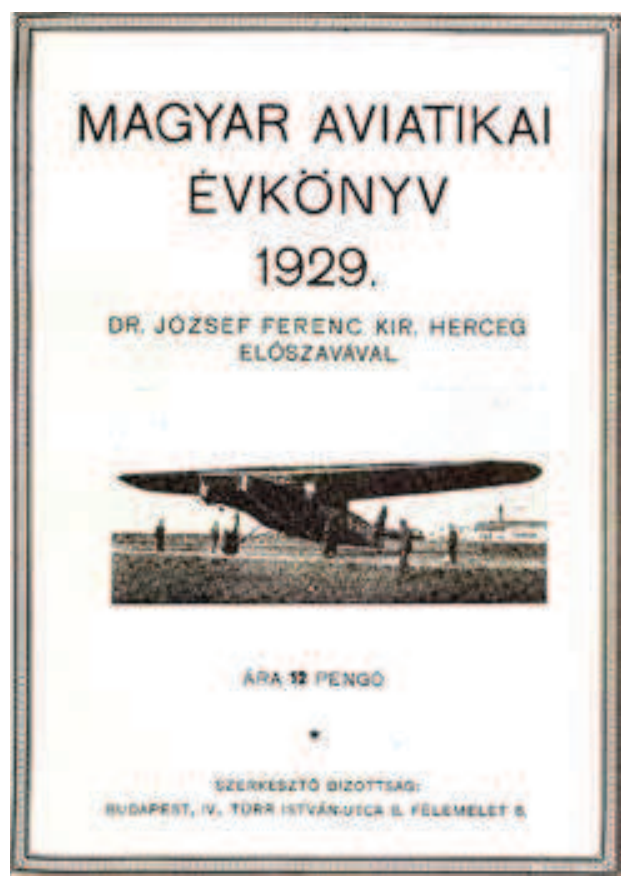

2. ábra. Az 1929-es Magyar Aviatikai Évkönyv

Az 1929-ben Dr. Merényi Scholtz Gusztáv légügyi orvos a magyar repülőorvostan alapjául szolgáló értekezést jelentetett meg „A repülés és az orvosi tudomány" címmel. Felismerései és megállapításai a kor színvonalán álló, vi- lágviszonylatban is a legkorszerübb elveket tükrözték. Máig ható tudományos igényű írásán repülőorvosi nemzedékek nevelkedtek fel. Értekezését 1993-ban a Magyar Repülőorvosok Lapja reprint kiadásban ismét megjelentette [7].

„A repüléssel kapcsolatban számos orvosi, élettani és közegészségügyi kérdés merült fel. Ily módon (sic!) új (sic!), alkalmazott tudományág keletkezett, melynek mai állásáról igyekszem majd e rövid tájékoztató keretén belül beszámolni. Vizsgálni fogjuk elöször, hogy a repülés milyen hatással van az emberi szervezetre. Azután tárgyalni fogjuk, hogy milyen testi és lelki kellékei vannak a repülögép vezetésnek (sic!) és milyen módon válogatjuk ki s ellenörizzük orvosilag a pilótajelölteket és a pilótákat. Végül röviden szó lesz a repülögépröl, mint beteg- és sebesültszállitó eszközröl" [8] - írta Dr. Merényi Scholtz Gusztáv tanulmánya bevezetőjében. Rámutatott, hogy a magassági repülés egyike a legfontosabb aviatikai orvosi problémáknak. Feltárta a magassági betegség patomechanizmusát. Foglalkozott a hypobarizmussal, a hypoxiával és a hypotermiával.

„A repülő tehát az emelkedésnél három fö változást észlel nevezetesen: 1. ritkább, kisebb nyomású levegőbe, 2. kisebb oxygéntartalmú levegöbe és 3. hidegebb levegőbe kerül" [9]. A repülőalkalmasság orvosi elbírálását fontosnak tartotta. Kifejtette, hogy a repüléshez teljesen ép és egészséges szervezet szükséges, ezért először klinikai vizsgálatnak vetették alá akkoriban a jelölteket és a pilótákat. A beválási statisztikákat elemezve azt találta, hogy a szervileg egészen ép emberek $15 \%$-a nem képes arra, hogy megtanuljon repülőgépet vezetni, további 15-20 \%-ából pedig csak közepes pilóta válik. Ezért szükségesnek látta már a húszas években a repülőszakorvosi vizsgálatok 
bevezetését is. Ennek keretein belül arra törekedett, hogy az összes olyan képesség vizsgálatra kerüljön, amely a repülögép vezetéséhez szükséges és amely más jármű vezetésétől megkülönbözteti.

Az alkalmasság megállapításánál vizsgálták a családi kórelőzményt, a lefolyt betegségeket és a szenvedélybetegségeket is (nikotin, alkohol, bódítószerek). Megítélték a testi kondíciót és az optimális életkort. A 20 évnél fiatalabbakat a repülés szempontjából még megbízhatatlanoknak tartották, a 30 évnél idősebbeket pedig, mivel nehezebben tanulnak, a kiképzésre alkalmatlannak minősítették. A már kiképzett pilóták felső életkori határát nem szabták meg, az egyéni elbírálás elvét alkalmazták. Az első világháborús tapasztalatok alapján a harci repülésnél a repülhető órák számát korlátozták.

„A repülögép vezetésnél (sic!) az idegrendszer is kopik. Ezt fóleg a világháborúban tapasztalták. Néhány évi repülés után egyik-másik pilóta érzi, hogy valami nincs rendben ideggépezetében. Überflogen mondták a németek, dégonflé - mondták a franciák, letört - mondhatnók magyarul. Mint a motornak, úgy a pilótának is van müködési időtartama. Az amerikaiak ezt is kiszámitották, és átlag kb. 200350 háborús pilóta munkaórában szabták meg. Békeidőben természetesen jóval hosszabb a müködési időtartam" - írta tanulmányában.

Figyelmet szenteltek az alkati sajátosságokra, felismerték, hogy a vézna, satnya jelöltek, vagy ellenkezőleg a „vaskos hústömegek, ahogy azokat a birkózóknál, és a súlyemelöknél látjuk", alkalmatlanok a repülőkiképzésre, mert hamar elfáradnak, gravitációs terhelhetőségük alacsony, a díjbirkózók pedig „rendesen ügyetlenek, durva mozgásúak, merevek, nehézkesek".

1941-ben a kolozsvári Ferenc József Tudományegyetemen magántanárrá ha- bilitálták, 1942-ben a Szegedi Egyetem magántanára lett, ezt a címét 19411944 között viselte, előadásait a szegedi és a kolozsvári egyetemen tartotta. Ez a kettősség némi magyarázatra szorul. Trianon után a Ferenc József Tudományegyetem 1921-ben Kolozsvárról Szegedre költözött. 1940-ben a második bécsi döntés értelmében Erdély visszatértével pedig az egyetem is részben visszaköltözött Kolozsvárra. Szegeden jogilag egy új egyetem, a Horthy Miklós Tudományegyetem létesült, zömében a régi tanárokkal. Így lett Dr. Merényi Scholtz Gusztáv mindkét egyetem magántanára. A szegedi hypobarikus hypoxiás vizsgálatai során famulusa az akkor medikus, később a nemzetközi hírnevet szerző hematológus Kelemen Endre professzor volt, aki az ő irányítása mellett kezdte el a hypoxiával kapcsolatos hematológiai kutatásait (3. ábra).

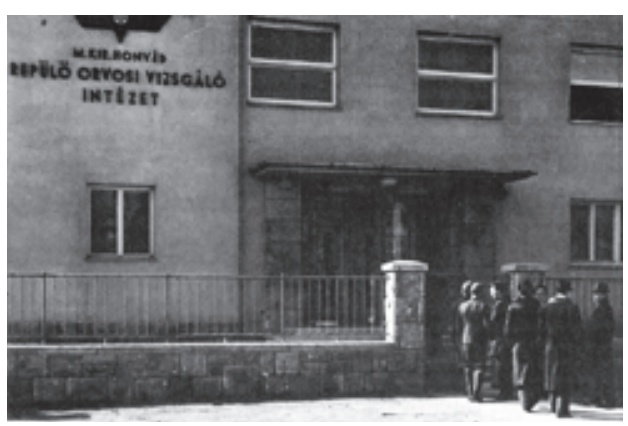

3. ábra. A Magyar Királyi Repülő Orvosi Vizsgáló Intézet új épülete 1943-ban a Karolina úton

1943-ban a Luftwaffe egészségügyi szolgálatának vezetője, Erich Hippke orvos vezérezredes (Generaloberstabsarzt Prof. Dr. med. Erich Hippke) német repülőorvosok társaságában látogatást tett Budapesten és megszemlélte a $\mathrm{m}$. kir. Légierők egészségügyi szolgálatát. A látogatókat Dr. Merényi Scholtz Gusztáv orvos alezredes, a m. kir. Légierők egész- 
ségügyi szolgálatának vezetője látta vendégül. A látogatás jól sikerült, a vendégek megismerkedtek a magyar repülő-egészségügyi szolgálattal és teljes képet kaptak a magyar repülőorvosi berendezésekről.

„A német orvosok több izben kifejezésre juttatták azt a véleményüket, hogy a kis államok közül Magyarország repülöegészségügyi berendezései és vizsgáló eljárásai a legjobbak, a magyar repülőorvosi kar képzettsége, szelleme és hivatástudata pedig egyenesen mintaszerü" [4] - írta a látogatásról a korabeli sajtó. A látogatás alkalmával Dr. Merényi Scholtz Gusztáv orvos alezredes tárgyalt egy új, nagyteljesítményü pótkocsis gépkocsira szerelt német gyártmányú mozgó barokamra, valamint a sebesültszállító „Storch” század repülőgépeinek leszállításáról és a kétmotoros sebesültszállító repülőgépek beszerzéséről is.

Dr. Merényi Scholtz Gusztáv orvos alezredes fontosnak tartotta, hogy a magyar repülőorvosi kar ne csak a szolgálat ellátásával foglalkozzon, hanem a fejlődést biztosító tudományos munkával is. A magyar repülőorvosi kar kutatómunkájával kapcsolatban kettős célt tűzött ki. Egyik célja volt, hogy felderítse a magassági betegség okát és a szervezet belsejében, a sejtben végbemenő legfinomabb zavarok hatásmechanizmusát, a másik pedig az, hogy kiderítse, miként lehetne a szervezetet a nagy magasságokhoz hozzászoktatni.

Ebbe a kutatómunkába igyekezett bevonni az egyetemi intézeteket is. Szoros együttmüködést alakított ki például a Tudományegyetem Kísérleti Fizikai Intézetével és a Müegyetem Aerodinamikai Intézetével is. Akkoriban adták át a Karolina út 29. száma alatt az új Repülőorvosi Vizsgáló Intézetet (ROVI), amely abban az időben Európa egyik legkorszerübb intézete volt (4. ábra).

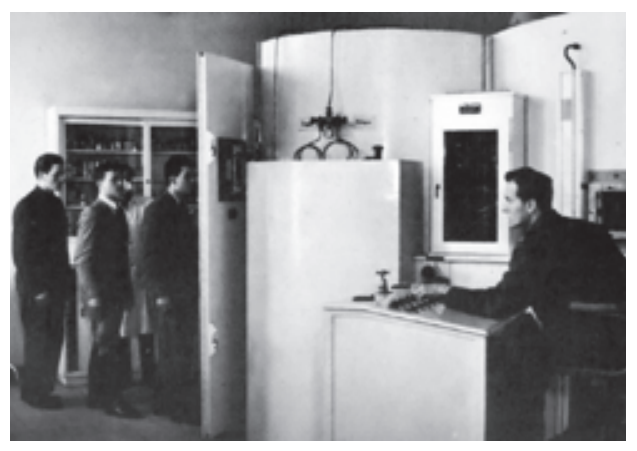

4. ábra. Vizsgálati személyek lépnek be a Müegyetemen elhelyezett barokamrába 1943-ban

A tervei szerint felépített, modern ROVI maradéktalanul alkalmas volt a jelöltek és a repülőhajózók időszakos alkalmassági vizsgálataira. Két belgyógyászati, kardiológiai, szemészeti, fül- és egyensúlyvizsgáló, röntgen-, ideg- és képességvizsgáló osztály, továbbá egy tornaterem kapott itt helyet. A szemészeti vizsgáló osztály Magyarországon a legkorszerűbb volt. A fül- és egyensúlyvizsgáló osztályt egy zaj- és vibráció-mentesített „csendes szobával” is felszerelték, ahol pontos hallásvizsgálatokat is el tudtak végezni. Abban az időben ez szintén egyedülálló volt hazánkban. A tornateremben a jelölteket nehéz fizikai megterhelésnek vetették alá, és így vizsgálták a ruganyosságukat, bátorságukat és kitartásukat (5. ábra).

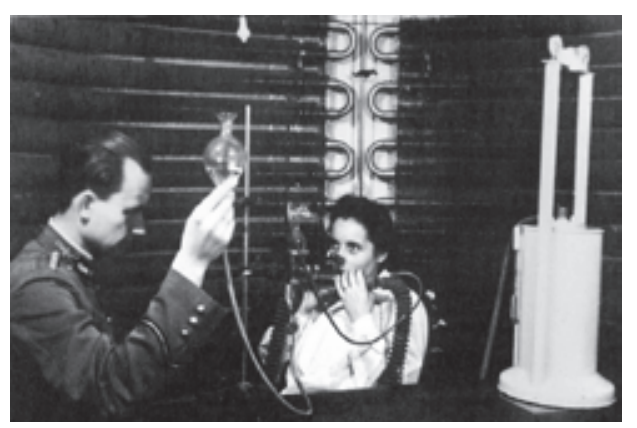

5. ábra. Légzésfunkciós vizsgálat a Müegyetemen elhelyezett barokamrában 1943-ban 
A magassági állomás a Múegyetem Aerotechnikai Intézetének épületében nyert elhelyezést. Itt vizsgálták a pilóta-, rádiós-, és lövészjelölteket, ha azok az előző vizsgálatokon már megfeleltek. A hypoxia-tűrőképességet három csoportra osztották és meghatározták az úgynevezett rezervidőt is, vagyis azt az időt, ameddig az oxigénszegény környezetben a pilóta munkaképességét meg tudja örzi. 5000 méteren egy órában, 6000 méteren fél órában, 7000 méteren 6-7 percben, míg 9000 méteren 2-3 másodpercben adták meg a rendelkezésre álló tartalék időt. Hihetetlen, de igaz, hogy ismerték már a túlnyomásos kabint és a „búvárruhaszerű túlnyomásos magassági repülööltözéket” is. A 12-14 ezer méteres magassági felszállás kísérleteiről azt írták, hogy az „... ezirányú kísérletek minden államban féltve örzött katonai titkok..." [10]. A magassági betegség tünetegyüttesét pontosan ismerték, és leírták: „a páciens elöször szaporábban szuszog, mélyebb lélegzetet vesz, arca is halványabb lesz; lassan finomabb mozgásaiban inkoordináció lép fel, például írásán rendkívül meglátszik a magasság hatása, elsősorban végtagjaiban rángó görcsök jelentkeznek... Szellemi téren a gondolkodásban egyre nagyobb kihagyások mutatkoznak... ezek a jelenségek egyre fokozódnak, végül hirtelen beáll az ájulás."

Dr. Merényi Scholtz Gusztáv orvos alezredes kiharcolta az önálló repülőpatikát is, amely Budapesten a Hunyadi János út 13. alatt müködött. „Kell lenni egy gyógyszertárnak, amelyben a repülötisztikar és a legénység legszélesebb körü gyógyszerigényét is ki tudjuk elégiteni" [5]. A légierők patikáját gyógyszervizsgálatok elvégzése céljából korszerü laboratóriummal is felszerelték. Tihanyi István gyógyszerész őrnagy vezette a repülőpa- tikát. Kívüle itt dolgozott Jámbor László gyógyszerész főhadnagy, Fabricziusz Imre gyógyszerész, és három karpaszományos okleveles gyógyszerész is. A pilóták fokozott vitaminszükségletének biztosítására polyvitamin készítményt dolgoztak ki és rendszeresítettek. A repülőpatika kizárólag honvéd intézmény volt, polgári egyént nem szolgáltak ki.

A repülö-egészségügyi szolgálat 1943-ban kapta meg a tábori mozgó barokamrát. A nagyméretű szerelvény egy dízel vontatóból és két pótkocsiból állt. Az egyik kocsin helyezkedett el az áramfejlesztő és a vákuumszivattyú. Az elektromos generátor lehetővé tette, hogy a mozgó magassági állomást akár terepen is, bárhol, ahol még elektromos áram sincs, müszereivel együtt, azonnal üzembe lehessen helyezni. A másik kocsin helyezték el az egyszemélyes barokamrát, amelyet az explozív dekompressziós vizsgálatokra használták és a kétszemélyes barokamrát, amelyet a hypoxia- és a dekompresszió türőképesség meghatározására, valamint a magassági kiképzésre, vagy ahogy akkor mondták a „magassági szoktató kísérletekre” használták. A mozgó magassági állomás rendszeresen látogatta a repülőcsapatokat és a pilótákat ellenörizte.

Előírták, hogy a magassági repülésre alkalmas hajózóknak 7000 méternek megfelelő hypoxiát oxigénlégzés nélkül 7 percen keresztül kell kibírniuk anélkül, hogy eszméletüket vesztenék. Ez olyan megpróbáltatás, amit kondicionálás nélkül egyetlen „normális, egészséges ember” sem bír ki ájulás nélkül. Kiderült azonban, hogy a szervezetet szoktatni lehet az extrém magasság elviseléséhez.

Dr. Merényi Scholtz Gusztáv a magassági szoktató barokamrás kísérleteket a légierők magassági kutatóin- 
tézetének stacioner, nagy kamrájában kezdte alkalmazni, de a kapacitás hamarosan elégtelennek bizonyult, ezért került sor a csapatoknál is a magassági kiképzésre. Oxigénlégzés nélkül 6000 méteren 5 percig, 7000 méteren pedig újabb 5 percig tartott a kiképzés. Eközben a felsőbb idegi tevékenységüket úgy ellenőrizték, hogy egy papírlapra ceruzával ezertől visszafelé kellett felírniuk helyes sorrendben a számokat. Kiképzés közben mérték a légzésszámot és a légzési volument is, életükre pedig egy repülőorvos vigyázott, a hypoxiás görcsrohamok jelentkezése esetén azonnal parancsot adott a sülylyedésre. Aki teljesíteni tudta 7000 méteren az 5 percet, az felemelkedhetett 8000 méterre is. A vizsgálat egyúttal a barofunkció ellenőrzésére és edzésére szolgáló zuhanó-próba is volt. Normális kiképzési helyzetben a vizsgálat végén a csúcsmagasságról 6000 méterre zuhantak, majd a dobüreg és az orrmelléküregek nyomáskiegyenlítése után tovább zuhantak 4000 méterre, ezután pedig 2000 méterre, ahonnan végrehajtották a leszállást. Kritikus helyzetben nem törődhettek a nyomáskiegyenlítődéssel, ilyenkor a zuhanás rendszerint erős fájdalmakkal, bevérzésekkel, dobhártyasérüléssel, különféle súlyosságú barotraumával járt [10].

Egyénenként állapították meg, hogy a magassági kiképzést követően mennyire nőtt a pilóták hypoxia-türőképessége. Meghatározták azt is, hogy egy kiképzés hatása hány hónapig tartott, és mikor kellett azt megismételni. A kedvező tapasztalatok alapján alakult ki az a repülőorvosi álláspont, hogy a magassági repülésre alkalmas pilótákat évente magassági kondicionáló sportkiképzésre kell kötelezni, mert ezáltal kifejlődik és egy éven keresztül fenn- marad a repüléshez szükséges mértékü hypoxia-türőképesség.

A magassági repülőknél bevezették a 14000 méteres felszállásokat is. Ez a vizsgálat a dekompresszió-türőképesség megállapítására szolgált. Ebben a magasságban már olyan alacsony a légnyomás, hogy a testnedvekben (föleg a vérben) a nitrogén buborékok alakjában felszabadul és az érrendszerben keringési elégtelenséget, az ízületekben pedig erös fájdalmakat okoz. Az életet veszélyeztető jelenség, ha előzőleg a keringő vérmenynyiség és a szervezet nitrogéntartalmának nagy részét tiszta (100\%-os) oxigénlégzéssel nem csökkentik a kritikus szint alá. A pilóták 14000 méteres felszállások alkalmával a korabeli legmodernebb, mütüdős, pillangószeleppel ellátott indikátoros, és vészadagolóval is rendelkező, korszerü oxigénálarcos berendezéseket használtak. A maszk hermetikusságát minden felszállás előtt gondosan ellenőrizték, a helyes használatra a pilótákat kiképezték, a vészhelyzetben fellépő légszomj esetére a szüntelen adagolású oxigéncsap használatára megtanították, mégis előfordult többször nagy magasságban a hirtelen eszméletvesztés. Ilyenkor a pilóta elörebukott a vizsgálóasztalra, beverte a fejét, és kisebb-nagyobb sérüléseket szenvedett el. Érdekes adat a magyar repülőorvostan történetében, hogy a magassági kollapszus esetén fellépő eszméletvesztés okozta mechanikai sérülések megelözése céljából a pilótákat a barokamrában (a feljegyzések szerint) kikötötték [10]. A magassági kamra fel volt szerelve az újraélesztéshez szükséges felszerelésekkel is. Több mint ötezer felszállást jegyeztek fel, halálos szövődményük nem volt.

Az explozív dekompressziós vizsgálatokat 3000 méteres magasságról 14000 méteres magasságra való „ugrással” vizs- 
gálták. Megállapították, hogy a robbanásszerű légnyomásváltozás hatására a szervezet folyadéktereiben oldott gázok kiválnak, a légtartalmú testüregekben elhelyezkedő gázok pedig sokszorosukra kitágulnak. Hatalmas puffadás, és veszélyes gázbuborékok alakulnak ki. Felismerték, hogy a repülés közben fellépö dekompressziós diszkomfort veszélyezteti a pilóták egészségét és hadrafoghatóságát, ezért speciális táplálkozásra van szükségük, a földi személyzettől elkülönített, úgynevezett hajózókonyha étlapjának összeállításánál az egészségügyi szempontokat figyelembe kell venni. Az explozív dekompressziós vizsgálatokat először a repülőorvosok magukon végezték.

1943-ban Dr. Merényi Scholtz Gusztáv, Dr. Korényi Zoltán és Dr. Gordon Helmut a magasság-türőképesség növeléséről számolt be a német repülőorvosi lapban [3]. Kísérleti eredményeik alapján megállapították, hogy heti két alkalommal 5000 méteres barokamrai magasságon eltöltött egyórás edzés hatására, a magasság-türőképesség a szöveti oxigén-felhasználás változásának következtében, 1000-2000 méterrel növelhető.

Másik közleményükben [11] rámutattak arra, hogy a magassági alkalmazkodás különböző típusait lehet megállapítani. Vannak, akik normális légzési és keringési állapotban alkalmazkodnak a nagy magassághoz, és vannak, akik a légzés fokozásával, mások a keringés fokozásával, és megint mások pedig a szöveti oxigén-felhasználás fokozásával. Megállapították az alkalmazkodás ötödik típusát, a kevert típust is, akik mind a légzés, mind a keringés fokozásával alkalmazkodnak a nagy magasságokhoz. Vizsgálataik repülőorvosi szempontból nagyon fontosak voltak, mert felfedezték, hogy egyesek anélkül tudnak a nagy magassághoz alkalmazkodni, hogy élettani tartalékukat túlságosan igénybe vennék, míg mások - bár alkalmazkodni képesek a hypoxiához - ezt nagyon nagy áron teszik, élettani tartalékukat e közben ki is merítik. Kézenfekvő, hogy az utóbbi személyek kevésbé alkalmasak olyan repülőszolgálatra, amely a szervezetre oxigénhiány mellett nagy fizikai és pszichikai megterhelést jelent.

Merényi az ország német megszállása (1944. márc. 19.) után bekapcsolódott a nemzeti ellenállási mozgalomba, csatlakozott Bajcsy-Zsilinszky Endre köréhez. Szálasi hatalomra jutása után állásából felfüggesztették. A nyilas uralom idején a vezetése alatt álló Pajor Szanatóriumban francia, orosz, bolgár hadifoglyokat bújtatott, üldözötteket menekített.

1945-ben aktív résztvevője volt a magyar katonaegészségügy ujjászervezésének, elöször a Budapesti Vöröskereszt Kórház parancsnoka lett (6. ábra).

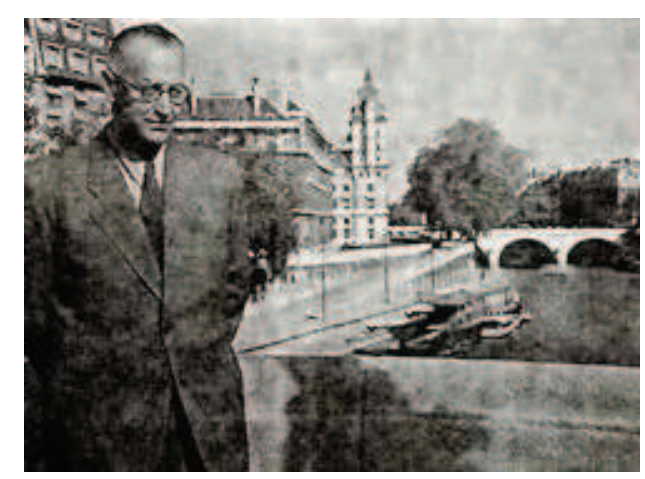

6. ábra. Dr. Merényi Scholtz

Gusztáv 1947-ben Franciaországi tanulmányútján Párizsban

1946-ban kinevezték vezérőrnaggyá és a Honvéd Orvosi Kar fönöke, majd a HM Egészségügyi Osztályának vezetője lett. Eközben 1947-ben két hónapot töltött Franciaországban és tanulmányúton ismerkedett a holland, belga, francia és az olasz Véradó Központ létreho- 
zásának körülményeivel. Tapasztalatai alapján 1948-ban itthon is megszervezte a magyar Véradó Központot és Véradó Állomást. A katonapolitikai helyzet alakulása miatt 1949-ben nyugdíjazását kérte. Azonban nyugállományba kerülésével sem tudta elkerülni, hogy az úgynevezett „tábornokok peré”-ben eljárás alá ne vonják. 1950. május 21-én tartóztatták le, a házkutatáskor lefoglalt összes személyes iratát és tudományos feljegyzését eltüntették, feltehetöen megsemmisítették.

A koncepciós eljárás során 66 katonai, rendőri, illetve polgári személyt vettek őrizetbe és ítéltek el. A perben 12 halálos ítéletet hoztak, melyből hetet végre is hajtottak, hat esetben pedig 10-15 évi fegyház, illetőleg életfogytiglan tartó kényszermunka ítélet született. A per célja az volt, hogy a két világháború között katonai végzettséget szerzett, ludovikás katonákat eltávolítsák a Magyar Honvédség vezetéséből. A megüresedett helyekre párthü, többnyire képzetlen fiatal katonákat helyeztek.

Ebben, az úgynevezett „tábornokok peré"-ben, amelynek Sólyom László altábornagy, vezérkari fönök volt a fővádlottja, 1950. augusztus 10-én ítélték halálra Dr. Merényi Scholtz Gusztávot is „a népi demokratikus államrend megdöntésre való szervezkedés és hütlenség büntette miatt" [12]. Terhükre rótták a szolgálati hatalommal való visszaélés büntettét is, amelyet azáltal követtek el, hogy a régi, úgynevezett nyugatos tiszteket fontos beosztásokba helyezték, az általuk irányított területeken szabotálták a hadsereg fejlesztését, gátolták a munkáskáderek érvényesülését. Szabó István 1950. július 31-ei szakértői véleménye szerint „reakciós, fasiszta tisztek visszavételével követték el a demokratikus államrend megdöntésére irányuló szervezkedést". Az ítéletet - amely a katonához méltatlan kötél általi halál volt - 1950. augusztus 19-én hajtották végre.

Az 1954-ben lefolytatott perújítás során a katonákat az alapper vádjai alól felmentették, de teljes rehabilitációjuk nem történt meg. A bíróság anyagaiból szinte kivétel nélkül az derült ki, hogy az önmagukra és társaikra adott beismerö vallomások kényszer hatása alatt születtek. Révész Géza, 1950-es ülnök szerint maga a tárgyalás annakidején 3-5 percig tartott, ahová azzal az utasítással érkeztek, hogy az I-IV. rendü vádlottakat halálra kell ítélni. A per bírója, Dr. Jávor Iván a tárgyalásra, s abban Farkas Mihály meghatározó szerepére a következőképpen emlékezett vissza 1957-ben: „Pál Ákos átadta a listát az itéletekröl. E szerint Sólyom, Illy, Beleznay, Révai, Porffy, Somogyi, Merényi és Lörincz ügyében olyan halálos itéletet kellett hozni, amelynek végrehajtására is sor került. Mivel sokalltam a halálos itéletek számát, felmentem Farkas Mihályhoz, hogy a Pál Ákos által megjelölteket kontroláljam. Farkas közölte velem, hogy amit Pál Ákos mondott az a párt álláspontja. ...Farkas Mihály konkrét utasitást adott, milyen itéleteket hozzunk. Rendkívül túlzott, majdnem mindenkit fel akart akasztani."

A Sólyom és társai ügyében 1954. szeptember 16-17-én megtartott perújítási tárgyaláson a Katonai Felsőbíróság a XII. rendü Dr. Merényi Gusztáv volt vezérôrnagy vádlottat a folytatólagosan elkövetett a demokratikus államrend és demokratikus köztársaság megdöntésére irányuló szervezkedés vezetésének büntette és folytatólagosan elkövetett hütlenség bűntettének vádjai alól bűncselekmény, illetve bizonyítékok hiányában felmentette. Más vádpontok alól (szolgálati hatalommal való visszaélés büntette és népellenes büntett) azonban nem 
mentette fel, csak az eljárást szüntette meg. A mai körülmények között hátborzongató olvasni az 1954-es bíróság szürreális megállapításait:

„Dr. Merényi Gusztáv orvos vezérör$n a g y$, mint az orvosi osztály vezetöje $k b$. 50 ezer darab orvosi müszer megjavitására nem tett intézkedést, holott erre beosztottai több alkalommal felhivták figyelmét. Baráti összeköttetésektöl vezetve tett javaslatot horthyista orvoskari tisztek visszavételére és vezetö beosztásba való helyezésre. Vádlottaknak ez a tevékenysége egy részét képezi azoknak a vádpontoknak, melyekben öket a katonai ügyészség eredetileg népi demokratikus államrend megdöntésére irányuló szervezkedés büntettével vádolta. Azt ugyan nem követték $e l$, de a szolgálati hatalommal való viszszaélés büntettét igen. Életben létük esetén ebben bünösségük megállapitható lenne és velük szemben e cselekményük miatt büntetést kellene alkalmazni. E vádpontok vonatkozásában azonban a Katonai Felsőbíróság - tekintettel arra, hogy vádlottak időközben meghaltak büntethetőséget megszüntetö ok címén a bünvádi eljárást megszüntette."

1956. október 13-án katonai tiszteletadás mellett a Farkasréti temetőben - a nyilvánosság teljes kizárásával - újratemették őket.

Erről az ítéletről 1990-ben a Magyar Köztársaság Legfelsőbb Bírósága megállapította, hogy törvénysértő volt, ezért hatályon kívül helyezte, a hütlenség és a népellenes büntettek alól büncselekmény hiánya miatt a vádlottakat felmentette. Megállapította továbbá, hogy a szervezkedésre vonatkozó tények és vallomások eredetileg is koholtak voltak.

Dr. Merényi Scholtz Gusztávot 2007ben posztumusz altábornaggyá lépették elö [13]. Emlékére a Gyáli úti Kórházat róla nevezték el (7. ábra).

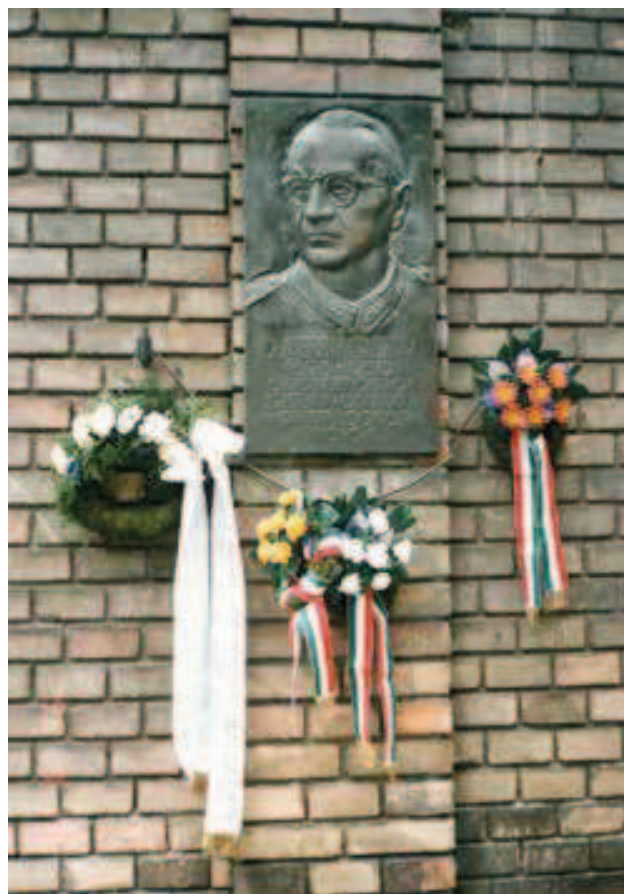

7. ábra. Dr. Merényi Scholtz Gusztáv emléktáblája a Gyáli úti kórházban

1990. szeptember 18-án ünnepeltük születésének 95. évfordulóját. Ebből az alkalomból a Merényi Kórházban ünnepi tudományos emlékülést szerveztünk, koszorút helyeztünk el az emléktábláján és a sírján. Dr. Hardicsay Gábor a Polgári Légiközlekedési Hatóság, Repülö-egészségügyi Osztályának hatósági főorvosa ünnepi beszédet mondott.

„Ma 95 éve, 1985. szeptember 18-án született Dr. Merényi Scholtz Gusztáv orvos vezérörnagy, a magyar orvosok kiválósága, a hazai repülőorvosi munka megalapozója. Az 1990-es év vele kapcsolatban több évfordulót is jelez. Így: 70 éve annak, hogy 1920-ban a budapesti Pázmány Péter Tudományegyetemen orvosi diplomát szerzett. 40 éve már, hogy 1950. augusztus 19-én a zsarnokság életét méltatlanul kioltotta. 1970. december 17. óta pedig - immár 20 éve - viseli kórházunk az Ő nevét" [14]. 
A Magyar Repülő- és Ürorvosi Társaság (MRÜT), az MH Kecskeméti Repülőkórház, valamint a Szegedi Tudományegyetem Repülő- és Ürorvosi Tanszéke 2006. október 26-án mellszobrot állított a repülőorvostan hazai megalapítója, a magyar katonaegészségügy kiemelkedő egyénisége, Dr. Merényi Scholtz Gusztáv orvos altábornagy emlékére. A kecskeméti repülőkórház aulájában felállított szobrot október 26-án, délután ünnepélyes keretek között Dr. Szekeres Imre honvédelmi miniszter leplezte le. A rendezvényen részt vett Tömböl László vezérőrnagy, a HM Honvéd Vezérkar fönökének helyettese, Dr. Németh András orvos dandártábornok, az MH Egészségügyi Parancsnokság parancsnokhelyettese, Bányai Gábor, a Bács-Kiskun megyei közgyülés elnöke, valamint $D r$. Zombor Gábor, Kecskemét polgármestere [15]. A honvédelmi miniszter ünnepi beszé- dében kiemelte: egy olyan ember szobrának avatására gyültek össze, akit szívesen magának tudna minden nemzet, aki egyszerre volt orvos, katona és a repüléshez értő szakember. Dr. Merényi Scholtz Gusztáv megalapozója volt a magyar haderő jelenlegi, magas színvonalon tevékenykedő egészségügyi szolgálatának, maradandót alkotott. Emlékeztetett arra, hogy 1936-ban, az ő tervei alapján állították fel az első magyar repülőorvosi vizsgálóintézetet, amelyet az MH Kecskeméti Repülőkórház jogelődjének tekint (8. ábra).

Dr. Grósz Andor orvos ezredes, a kecskeméti Repülőkórház főigazgatója, a MRÜT fötitkára megemlékezésében elmondta, hogy szobrot állítottak annak a katonaorvosnak, aki az 1930-as évektöl kezdődően mintegy húsz éven keresztül azon munkálkodott, hogy a repülőtechnika fejlődéséből adódó orvosi kérdések

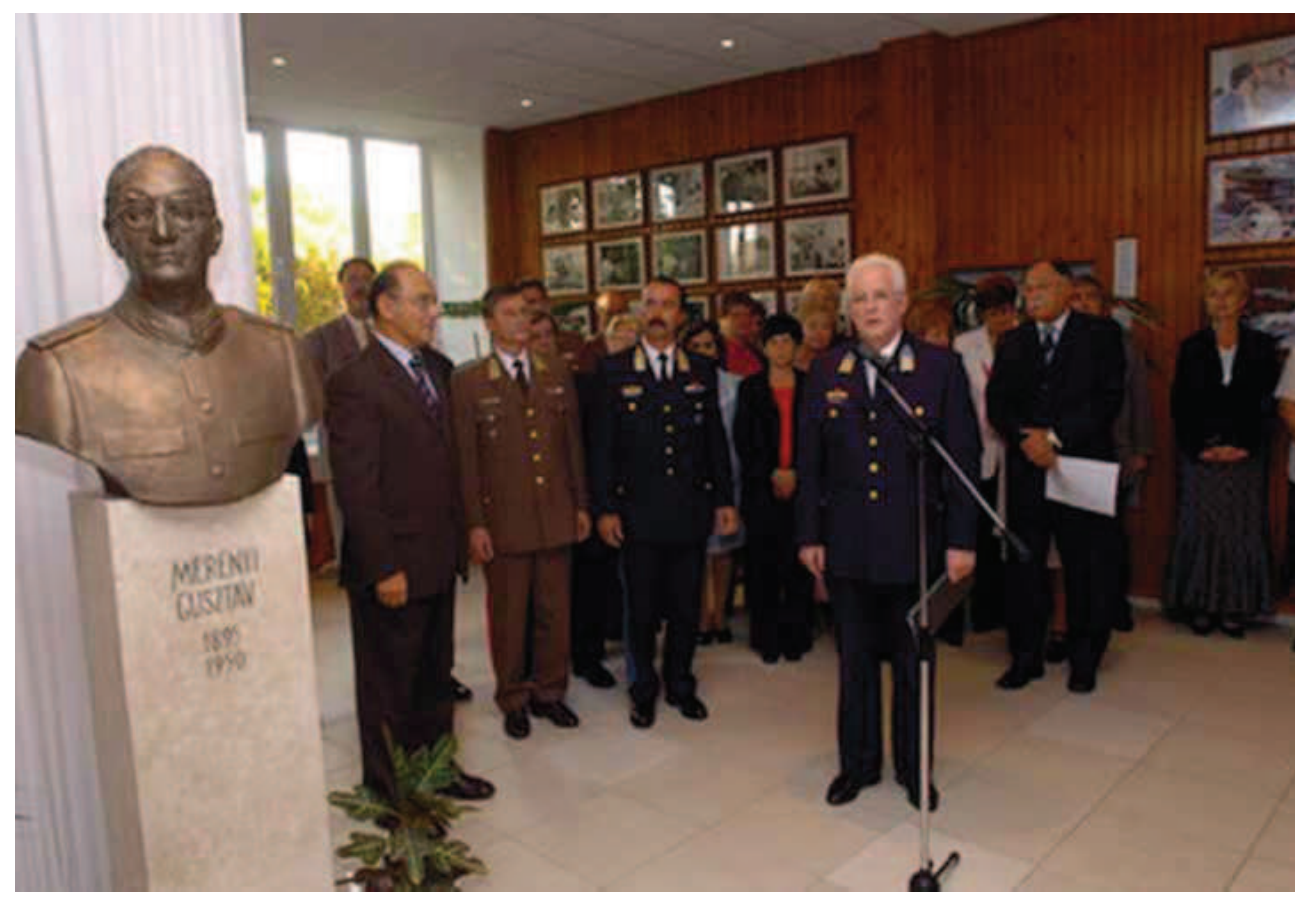

8. ábra. 2006-ban Dr. Merényi Scholtz Gusztávról szobrának avatásán Dr. Grósz Andor orvos ezredes mondott beszédet 
megválaszolására a pilóta, és az őt alkalmasnak minősítő, valamint felkészítő orvosok készen álljanak. Dr. Grósz Andor orvos ezredes emellett megköszönte a szobor alkotójának, Benedek György, Munkácsy-díjas érdemes szobrászmüvésznek munkáját is, aki hitelesen tudta visszaadni a nagyszerü katonaorvos tartását, vonásait.

\section{Irodalom}

[1] Scholtz G.: A repülés és az orvosi tudomány. Magyar Aviatikai Évkönyv. 1929, 214-229.

[2] Abody (Anderlink) E.: A repülőgép és a repülés. Pósa Károly könyvkereskedő kiadása. Budapest. 1942, 593-611.

[3] Scholtz v. Merényi, G., Korényi Z., Gordon H.: Über die Steigerung der Höhenfestigkeit durch wiederholte U-Kammeraufstiege. Luftfahrtmedizin, 1943, 8(4): 331-338.

[4] László I.: Scholtz orvosalezredes a m. kir. légierők egészségügyi szolgálatáról. Magyar Szárnyak. 1943, 6(6): 8.

[5] Raczkó L.: A magyar repülőpatika. Magyar szárnyak. 1943. Fénymásolat. Repülőorvosi archívum Kecskemét. RAK 19430020.

[6] Vesztényi J.: A magyar katonai repülés 19201945. 4. fejezet. Kézirat.: 68-70. Vértessy Sándor: Hadtörténeti kutatás iratanyaga. Repülőorvosi archívum Kecskemét. RAK 19200000 .

[7] Merényi Scholtz G.: A repülés és az orvosi tudomány. Magyar Repülőorvosok Lapja. 1993, 1.(1-2)

[8] Scholtz G.: A repülés és az orvosi tudomány. Magyar Aviatikai évkönyv. 1929. Budapest. pp. 214-229.

[9] u.o.: p. 217.

[10] Raczkó L.: A honvéd légierők mozgó magasságvizsgáló állomása. Magyar szárnyak. 1943.
8. p. Fénymásolat. Repülőorvosi archívum Kecskemét. RAK 19430010.

[11] Gordon H., Korényi Z., Scholtz v. Merényi, G.: Über den Mechanismus der Höhenumstellung bei schnell eintretender Hypoxie. Luftfahrtmedizin, 1943, 8(4): 290302.

[12] Schubert Katalin: A tábornokok pere. PhD értekezés. Zrínyi Miklós Nemzetvédelmi Egyetem Hadtudományi Doktori Iskola, Budapest, 2006.

[13] Magyar Közlöny. 2008/141. sz.

[14] In memoriam Merényi-Scholtz Gusztáv. Hardicsay Gábor beszéde Dr. Merényi Scholtz Gusztáv születésének 95. évfordulóján. Kézirat. 1990. Repülőorvosi archívum Kecskemét. RAK 19900918.

[15] www.hovedelem.hu., 2006.

\section{Col. (ret.) P. Remes MD, PhD}

\section{In memoriam Lt.Gen. Merényi Scholtz Gusztáv MD}

Lt. Gen. Gusztáv Merényi Scholtz MD (1895-1950) has gained imperishable distinction in creating and organizing the Hungarian Military Aviation Medicine. He established with productive arrangement a non-existing before and advanced air-force medical service in Hungary after the Treaty of Trianon.

Keywords: Hungarian Royal Air Force Medical Services, Hungarian Royal Aeromedical Institut, Aviation and Medicine, Decompression Sickness, Prevention of Hypoxia, Pressure Cabin

Dr. Remes Péter ny. o. ezds. PhD 6000 Kecskemét, Balaton u. 17. 